КОМПОНЕНТИ КУЛЬТУРИ ПРОФЕСІЙНОЇ ДІЯЛЬНОСТІ МАЙБУТНІХ МЕНЕДЖЕРІВ

\title{
THE COMPONENTS OF CULTURE IN FUTURE MANAGERS' PROFESSIONAL ACTIVITY
}

у статті розкрито сутність поняття «менеджер», «профресійна культура». Подано авторське визначення поняття «культура професійної діяльності майбутніх менеджерів», що розглядається як високий рівень профессіналізму людини, як спосіб творчої самореалізації в професійній діяльності, як процес освоєння, передачі професійних цінностей, становлення системи особистісних сенсів, які розглядаються як ступінь якості професійної діяльності та життя людини. Розкрито зміст і структуру культури професійної діяльності майбутніх менеджерів, що складається з гностичного, конструктивного, організаторського та комунікативного компонента. Охарактеризовано складові компоненти культури профресійної діяльності майбутніх менеджерів, а саме: особистісний, когнітивний, діяльнісний. Визначено низку функцій культури професійної діяльності майбутніх менеджерів, як-от: адміністраторська, стратегічна, експертно-консультативна, представницька, виховна, інноваційна, психотерапевтична комунікативно-регулююча, дисциплінарна. Окреслено ролі менеджера в організаціі будь-якого прочесу: роль прийняття рішень, інформаційна, роль керівника. Акцентовано на значущості особистісних аспектів для майбутньої успішної професійної діяльності менеджерів, а саме: вмінні побудувати довірливі відносини з колегами, підлеглими, клієнтами; розвиненні комунікативні здібності, вміння вислухати та прислухатися до співрозмовника, ораторські здібності; вміння керувати своїми почуттями та емоціями, організувати спільну роботу в команді. Визначено головні тенденції, що відбуваються в сучасній концепції менеджменту, серед яких: лідерство, комунікація, профе сійне знання. Теоретичною і методичною основою дослідження $\epsilon$ системний підхід до вивчення фрундаментальних положень культури професійної діяльності майбутніх менеджерів. Для вирішення поставлених завдань використано такі загальнонаукові методи, як метод аналізу і синтезу (3 метою характеристики понятійно-категоріального апарату дослідження), науковоі абстракції, індукції та дедукції (при узагальненні вітчизняного та зарубіжного досвіду формування культури профресійної діяльності майбутніх менеджерів). Доведено, що зміст готовності майбутніх менеджерів до управлінської діяльності являє собою динамічне структурно-рівневе утворення, що відображає єдність особистісного, когнітивного та діяльнісного компонентів.
Ключові слова: професійна культура, культура професійної діяльності, менеджери.

The article describes the essence of the concept of "manager", "professional culture". The author defines the concept of "culture of professional activity of future managers", which is considered as a high level of professionalism of the person, as a way of creative self-realization in professional activity, as a process of development, transfer of professional values, the formation of a system of personal meanings, which are considered as a degree of quality of professional activity and life. The content and structure of the culture of professional activity of future managers, consisting of a gnostic, constructive, organizational and communicative component, are revealed. The components of the culture of the professional activity of future managers, namely personal, cognitive, activity, are characterized. A number of functions of the culture of professional activity of future managers, such as administrative, strategic, expert-consultative, representative, educational, innovative, psychotherapeutic, communicative-regulating, disciplinary, have been determined. The role of the manager in the organization of any process is outlined: the role of decision-making, information, the role of the manager. Emphasis is placed on the importance of personal aspects for the future successful professional activity of managers, namely the ability to build trusting relationships with colleagues, subordinates, clients; developed communication skills, ability to listen and listen to the interlocutor, oratorical skills; ability to manage their feelings and emotions, organize teamwork. The main tendencies that occur in the modern management concept are identified, among them: leadership, communication, professional knowledge. The theoretical and methodological basis of the study is a systematic approach to the study of the fundamental provisions of the culture of professional activity of future managers. To solve these tasks, such general scientific methods as: the method of analysis and synthesis (to characterize the conceptual and categorical apparatus of research) were used; scientific abstraction, induction and deduction (when generalizing domestic and foreign experience of forming the culture of professional activity of future managers). It is proved that the content of the readiness of future managers for management activity is a dynamic structural-level formation that reflects the unity of personal, cognitive and activity components.

Key words: professional culture, professional culture, managers.
Донбаського державного педагогічного університету
Постановка проблеми в загальному вигляді. Значна роль у процесі розвитку належить системі вищої освіти. На перший план у процесі навчання в закладі вищої освіти виходить підготовка фрахівця з нестандартним мисленням, готового до практичної діяльності, налаштованого на успіх у будь-якій сорері, того, хто може ефективно діяти в умовах невизначеності, брати на себе відповідальність за соціальні перетворення та бути носієм культури професійної діяльності. В умовах сьогодення культура професійної діяльності $€$ основою конкурентоспроможності майбутніх фрахівців. Соціально-економічний та соціальний розвиток суспільства висуває нові вимоги до професійної 
підготовки майбутніх менеджерів, а саме: неперервне навчання впродовж життя, яке має поєднуватись із творчістю, вмінням працювати в колективі й особистою відповідальністю за результати праці. Тому завдання закладу вищої освіти полягає в розвитку професійно важливих якостей майбутніх менеджерів, які б успішно давали змогу виконувати майбутні професійні завдання. В умовах глобалізаційного розвитку суспільства особливої гостроти набуває питання якісної підготовки майбутніх менеджерів організацій, оскільки їх діяльність $€$ багатофункціональною і сприяє розвитку науки, виробництва, технологій надання послуг, духовного життя суспільства. Процес фрормування культури профресійної діяльності вимагає перегляду та вдосконалення змісту вищої освіти, методів навчання та виховання майбутніх фрахівців в умовах сучасної вищої освіти.

Отже, культуру професійної діяльності майбутніх менеджерів маємо розглядати як високий рівень профресіоналізму людини, як спосіб творчої самореалізації в профресійній діяльності, як процес освоєння, передачі професійних цінностей, становлення системи особистісних сенсів, які розглядаються як ступінь якості професійної діяльності та життя людини.

Аналіз останніх досліджень і публікацій. Дослідженню проблеми культури професійної діяльності майбутніх менеджерів приділяється належна увага в багатьох наукових дослідженнях, зокрема, таким ії аспектам: професійне становлення майбутніх менеджерів (Т. Глушман, В. Горланчук, І. Дороховський, С. Петько, І. Черноіванов, Т. Прехул, П. Друкер, В. Зобов та ін.); теорія та практика підготовки до управлінської діяльності (І. Аннєнкова, О. Виханський, І. Драч, О. Ельбрехт, C. Самигін, Е. Печерська та ін.); роль і значення цінностей особистості в профресійному самовизначенні та професійній діяльності (Л Белкер, А. Бербердін, Т. Стеранюк, Л. Хілл та ін.); теоретико-методологічні засади підготовки майбутніх фахівців у навчально-виховній діяльності закладу вищої освіти (С. Архипова, І. Бех, С. Вітвицька, Н. Ничкало, В. Стрельніков, М. Фіцула та ін.); вивчення нових цілей, принципів і методологічних підходів у освітньому процесі закладу вищої освіти (Е. Волков, К. Альбуханова-Ставська, А. Брушлинський, В. Татенко, В. Андреєва, Г. Ващенко, В. Гриньов, Л. Петько, В. Тернопільська, Н. Чернуха та ін.); формування професійної культури майбутніх менеджерів (Л. Батченко, О. Виговська, М. Гриньова, М. Дробноход, М. Захаров, В. Жигір, Л. Каращук, Н. Коломинський, О. Крупський, С. Крисюк, $€$. Намлієв, Р. Шакуров та ін.) [3; 8; 9; 10; 13-21].

Виділення не вирішених раніше частин загальної проблеми. Акцентуючи на вагомому внеску вітчизняних і зарубіжних науковців у розв'язання проблеми фрормування культури професійної діяльності майбутніх менеджерів, Т. Глушман наголошує [3], що нині $€$ протиріччя між постійно зростаючими потребами економічного сектору країни у фрахівцях 3 ефективно сорормованою культурою професійної діяльності та якістю їх фрахової підготовки, що не враховує сучасних потреб та вимог сучасного ринку праці. Саме тому важливим $є$ виокремлення та наукове обґрунтування компонентів культури профресійної діяльності майбутніх менеджерів.

Мета статті полягає у виокремленні та науковому обґрунтуванні компонентів культури профресійної діяльності майбутніх менеджерів.

Виклад основного матеріалу. У розвинених зарубіжних країнах немає єдиного погляду на роль менеджера в суспільстві як професійно підготовленого фрахівця. Американські науковці [2] першими розробили концепцію менеджменту, охарактеризувавши роль менеджера як фахівця, який має вищу професійну освіту, зазвичай як доповнення до економічної, юридичної, інженерної. Так, засновник класичної школи управління А. Файоль визначає менеджера як такого, що виконує професійно складні управлінські функції, $є$ «обчислювальною машиною, яка логічно думає». Він повинен володіти достатніми знаннями для вирішення управлінських, технічних, комерційних і фрінансових питань, мати достатню фрізичну й інтелектуальну міць і працездатність, щоб узяти на себе весь тягар проблем і ділових зобов'язань [4].

У сучасних наукових джерелах менеджер характеризується як людина, що має спеціальну фрахову підготовку та здійснює управління організацією, підрозділом або напрямом діяльності (кадрами, фрінансами, матеріальними чи інфрормаційними ресурсами, інноваціями в умовах сучасного ринку), володіє відповідними профресійними знаннями, уміннями та навичками, отриманими у відповідному закладі вищої освіти, здатна організовувати конкретну діяльність підлеглих та кваліфіковано виконувати свої управлінські фрункції [3; 4].

На думку Е. Печерської, за змістом професійна діяльність менеджера характеризується суто практичною, пошуковою та інноваційною діяльністю, що включає в себе потужні проектно-конструкторські, проектно-технологічні та практико-інноваційні компоненти [11].

Як зазначає А. Зобов, нині на перший план виходять не раціонально-прагматичні аспекти управління, а соціально-психологічні, тобто особистісні компоненти людської діяльності [5]. Тому серед головних тенденцій у сучасній концепції менеджменту перше місце посідають лідерські якості як здатність вести за собою людей, комунікація як здатність до безперервного спілкування, яке $€$ профресійно орієнтованим на передачу не тільки управлінської інфрормації, але й деяких імпульсів до дії, а також на отримання зворотного 
зв'язку і зворотної інфрормації, профресійне знання з точки зору основ управління загалом.

Науковець Л. Белкер акцентує на значущості особистісних аспектів для майбутньої успішної професійної діяльності менеджерів, а саме: вміння побудувати довірливі відносини з колегами, підлеглими, клієнтами; розвинені комунікативні здібності, вміння вислухати та прислухатися до співрозмовника, ораторські здібності; вміння керувати своїми почуттями та емоціями, організувати спільну роботу в команді [3; 16].

Аналіз наукової літератури з проблеми дослідження дав змогу Т. Глушман створити загальну картину, яка відображатиме специфіку цієї діяльності, і визначити ії як інноваційну, пов'язану зі спілкуванням, необхідністю установки безпосередніх або опосередкованих контактів з іншими людьми [3]. У рамках цієї діяльності менеджеру висуваються певні вимоги, що знаходять своє втілення в його рольових, функціональних та якісних характеристиках. Розглядаючи структуру профресійної діяльності майбутніх менеджерів, С. Самигіна і Л. Столяренко виділяють такі компоненти культури професійної діяльності майбутніх менеджерів: гностичний, конструктивний (проектний), організаторський і комунікативний. Гностичний компонент дослідники пов'язують зі сорерою знань і умінь, що становлять основу культури професійної діяльності, а система знань включає як загальнокультурні, так і спеціальні знання; проектувальний і конструктивний компоненти - вміння постановки перспективних цілей діяльності, розробку стратегій з їх досягнення та забезпечення реалізації тактичних цілей, тобто уміння планувати свою діяльність з урахуванням найближчих завдань; організаторський компонент відображає вміння організовувати власну діяльність та вміння організовувати діяльність оточуючих; комунікативний компонент акцентує на вмінні організовувати взаємодію менеджера з оточуючими його людьми [12].

Деякі вчені, роблячи акцент на психологічних моментах культури профресійної діяльності менеджера, розглядають її з погляду функціонального підходу (В. Горланчук, Р. Кричевський, Е. Кузьмін, Р. Куїнн, С. Мартинов, В. Рижиков, М. Томпсон, С. Фаєрман та ін.) і виділяють низку функцій: адміністраторську, стратегічну, експертно-консультативну, представницьу, виховну, інноваційну, психотерапевтичну, комунікативно-регулюючу, дисциплінарну [3; 7].

Як зазначають О. Виханский та А. Наумов, в організації будь-якого процесу на менеджера покладено відповідальність щодо прийняття рішень, адже саме він, будучи наділеним правом прийняття рішення, несе відповідальність за наслідки прийнятого рішення (роль прийняття рішень), збір інорормації про зовнішнє і внутрішнє середовище, поширення ії у вигляді фрактів і нормативних установок (інформаційна), срормування відносини усередині і поза організацією, що мотивуватимуть працівників, координуватимуть їхні дії (роль керівника) [1].

Складовими компонентами культури профресійної діяльності А. Омаров визначає такі: освоєння загальної культури, залучення до її досягнень; оволодіння профресійною майстерністю, повна творча реалізація профресійних навичок; профресійна компетентність у своєму виді діяльності; грамотне, еорективне використання засобів і методів у процесі досягнення мети; раціональність, розважливість під час виконання своєї роботи; можливість передбачення результатів праці; здатність і бажання передати свої вміння, знання, навички; культура спілкування та морально-професійна етика [7].

Компонентами культури професійної діяльності майбутніх менеджерів визначають: особистісний (ціннісне ставлення особистості до вибраної профресії, наявність загальнолюдських цінностей й цінностей профресійної самореалізації, готовності до виявлення особистої ініціативи й подальшого професійного зростання, наявність моральних якостей особистості, оцінювання власної професійно-культурної діяльності крізь призму високих моральних якостей, культурних цінностей та норм); когнітивний (засвоєння ґрунтовних загальнокультурних та специфічних професійних знань, технології їх використання в профресійній діяльності, знання норм моральної та етичної поведінки, етики ділового спілкування, знання методів самоаналізу та адекватної самооцінки, методів та прийомів саморозвитку та самовиховання); діяльнісний (уміння практично використовувати набуті теоретичні знання, дотримання морально-етичних норм у суспільстві та професійній діяльності, здійснення самоаналізу власної професійної діяльності та розвитку професійної культури, знаходження шляхів до самовдосконалення та реалізації потреб самоактуалізації в професії). Важливо, що саме особистісний компонент культури професійної діяльності майбутніх менеджерів відіграє ключову роль, тому що основні принципи організації задають певний напрям для функціонування суб'єкта, а також визначають його норми та цінності [3, с. 11].

Зміст готовності майбутніх менеджерів до управлінської діяльності являє собою динамічне структурно-рівневе утворення, що відображає єдність особистісного, когнітивного та діяльнісного компонентів.

Висновки. Отже, зміст культури професійної культури діяльності майбутніх менеджерів являє собою динамічне структурно-рівневе утворення, що відображає єдність особистісного, когнітивного та діяльнісного компонентів. Особистісний компонент виражено в ціннісному ставленні до профресії, усвідомленні її значущості для суспільства, 
позитивному ставленні до себе як майбутнього фрахівця у сорері менеджменту, наявності моральних якостей особистості, необхідних для ефрективної міжособистісної профресійної взаємодії. Когнітивний компонент відображає засвоєння загальнокультурних та специфічних професійних знань здійснення управлінської діяльності, знання методів та прийомів самоаналізу, саморозвитку та самовиховання, знання норм моральної та етичної поведінки. Діяльнісний компонент - уміння продуктивно застосовувати теоретичні знання у професійній діяльності, здійснення об'єктивної самооцінки професійної діяльності та розвитку культури професійної діяльності, дотримання норм моральної та етичної поведінки (за Т. Глушман). Культуру профресійної діяльності майбутніх менеджерів розглядаємо як важливий механізм, який впливає на вмотивованість, розвиток профресіоналізму, творчу самореалізацію в майбутній профресійній діяльності, процес освоєння та передачі професійних цінностей особистості. Вона позначає просресійну компетентність менеджера через усвідомлення себе як носія культурних зразків поведінки та професійної діяльності, фрормування позитивного ставлення до професійної діяльності, колег, клієнтів. Перспективи подальших наукових розвідок полягають у науковому обґрунтуванні психолого-педагогічних аспектів фрормування культури професійної діяльності майбутніх менеджерів.

\section{БІБЛІОГРАФІЧНИЙ СПИСОК:}

1. Виханский О.С. Менеджмент : учебник. 6-е изд., перераб. и доп. Москва: Магистр: ИНФРА-М, 2014. 656 c.

2. Горлачук В.В, Яненкова І.Г. Економіка підприємства : навч. посібник. Миколаїв : Вид-во чдУ ім. Петра Могили, 2010. 344 с.

3. Глушман Т.М. Компоненти профресійної культури майбутнього менеджера організацій. Scientific Journal «ScienceRise: Pedagogical Education» 2016. № 5 (1). C. 8-13.

4. Друкер П.Ф. Энциклопедия менеджмента. Москва : Издательский дом «Вильяме», 2004. 432 с.

5. Зобов А.М. Бизнес-образование: новые подходы к формированию личности. Дополнительное профрессиональное образование. 2005. № 5. С. 1-4.

6. Кричевский Р.Л. Если Вы - руководитель.. Элементы психологии менеджмента в повседневной работе. Москва : «Дело», 1993. 352 с.

7. Омаров А.М. Управление: искусство общения. Москва : Сов. Россия, 1983. 237 с.

8. Петько Л.В. Иноязычное обучение будущих менеджеров образовательной сореры в условиях университетской подготовки. Инновации в образовании : научно-методический журнал / учред. Современная гуманитарная академия; гл. ред. И.В. Сыромятников. Москва : Современная гуманитарная академия, 2013. № 12. C. 36-45.

9. Петько Л.В. Підготовка нового педагога-економіста - виклик сучасній педагогічній університетській освіті (на прикладі створення нових навчальних програм 3 іноземної мови за фрахом зі спеціальності 6.030601 «Менеджмент (управління персоналом)». Вісник Інституту розвитку дитини. Вип. 27. Серія: Філософрія, педагогіка, психологія : збірник наук. пр. Київ : Вид-во НПУ імені М.П.Драгоманова, 2013. С. 95-101.

10. Петько С.М. Моделі корпоративного управління в діяльності корпорацій на світових ринках. Молодий вчений. 2015. № 2 (17). Ч. 2. С. 225-229.

11. Печерская Э.П. Концептуальные аспекты подготовки конкурентоспособного специалиста в современных условиях. Самара : Изд-во Самар. гос. экон. акад., 2003. 260 с.

12. Самыгин С.И., Столяренко Л.Д. Менеджмент персонала. Ростов-на-Дону : Феникс, 1997. 480 с.

13. Чернуха Н.М. Інтеграційні процеси у вищій школі : навч. посібник. Київ : Київський університет імені Бориса Грінченка, 2015. 92 с.

14. Babiy S., Bezkorovaina O., Matviienko O., Petko St., Ternopilska V., Soichuk R., Stanislavchuk N. Entrepreneurship model of professional development of actuaries in Canada. Journal of Entrepreneurship Education (JEI). USA. 2019. Vol. 22. Issue: 3.

15. Belker L.B. The first-time manager. 4-th ed. New York: AMACOM. Amer, management assoc., 1997. 21 p.

16. Bezkorovaina O., Kulyk O., Ovsiienko L., Pet'ko L., Soichuk R., Turchynova G., Stanislavchuk N. Entrepreneurship Education of Future Travel Managers. Journal of Entrepreneurship Education (JEI). USA. 2019. Vol. 22(6).

17. Bodnarchuk O., Bodnarchuk Oks., Ersozoglu R., Kanishevska L., Pet'ko L., Turchynova G., Vyshnivska $\mathrm{N}$. Model of entrepreneurial corporate education and prospects of professional development of managers in Ukraine. Journal of Entrepreneurship Education (JEI). USA. 2019. Vol. 22. Issue: 2.

18. Brovko K.A., Ternopilska V.I. Corporate culture of personality: psychological aspects. Topical issues of contemporary science: Collection of scientific articles. C.E.I.M., Valencia, Venezuela, 2017. PP. 176-178.

19. Hlushko L., Ternopilska V. Self-confidence: theoretical analysis. Problems of the development of modern science: theory and practice: Collection of scientific articles. - EDEX, Madrid, España, 2018. P. 192-196.

20. Pet'ko L. The development of student youth aesthetic culture on professional direction. Topical issues of contemporary science: Collection of scientific articles. C.E.I.M., Valencia, Venezuela, 2017. P. 188-192.

21. Ternopilska V.I. The role of self-government in development of leadership qualities among students. Problems of development modern science: theory and practice: Collection of scientific articles. EDEX, Madrid, España, 2016. P. 327-330. 